\title{
Enhancing Community Resilience via Sustainable Management of Abandoned Paddy Lands in Bentota, Sri Lanka
}

\author{
Ranjana.U.K. Piyadasa ${ }^{2}$,T.K.G.P. Ranasinghe ${ }^{1}$ and H.M.M.S.D.Herath ${ }^{2}$ \\ ${ }^{1}$ Department of Environmental Technology, University of Colombo, \\ ${ }^{2}$ Department of Town and Country Planning, University of Moratuwa,
}

\begin{abstract}
Salt water intrusion (SWI) and coastal salinity are major causes for abandoning the paddy lands in Sri Lanka. More than $80 \%$ of paddy lands in left bank of Bentota River basin have been progressively abandoned due to contrasting degrees of saltwater intrusion by intimidating for agriculture, fishery, tourism and ground water in the area. This study was conducted applying the toolkit for the Indicators of Resilience in Socio-ecological Production Landscapes and Seascapes (SEPLS, 2014) through stakeholder perception based approach. Indictor scores and trend analysis indicate that there is a negative trend in resilience capacity of Bentota landscape in terms of abandoning the paddy lands. Several issues in contradiction of the utilization of abandoned paddy lands and the location specific land management strategies for utilizing abandoned paddy lands were identified by consulting prospective stakeholders of the area for enhancing community resilience without undermining their eco-social basis. New technological innovations as outcome of recent research and development initiatives can be introduced and promoted among the stakeholders in the area who would be the pillars for regaining the successive agriculture in Bentota area by enhancing the land productivity of abandoned paddy lands towards the sustainable land management.
\end{abstract}

Key words: salt water intrusion, degradation of paddy lands, community resilience 


\section{Introduction}

Salt water intrusion has been identified as the main problem for abandoning the paddy lands in Bentota area and out of the 2524 ha of paddy lands cultivated in year 1983 only 245 ha of paddy lands have been cultivated during year 2013. The loss of annual income from agriculture due to the salt water intrusion and land degradation in the area can be assessed as 3,624,000 USD during year 2017 that making huge threat for local economy of the area. Therefore, $52 \%$ from the total population was economically not active with the reduction of agricultural sector in the area. However, the Bentota river basin is below the agricultural production capacity level and no any strategy has been implemented or introduced so far regarding utilizing these vast amounts of abandoned paddy lands in the area. Therefore as the case study for this research, Bentota Divisional Secretariat Division (DSD) area situated in left bank of Bentota river basin was selected to identify sustainable land management strategies for utilizing abandoned paddy lands while enhancing community resilience without undermining their eco-social basis. This paper explains the important literature for highlighting the research problem and the details of SEPLS toolkit which applied in this study as the main method for data collection and analysis. Finally remarkable findings of this study are explained as development initiatives which can be promoted among the prospective stakeholders in the area for regaining the successive agriculture in Bentota area.

\section{Literature Review}

According to Intergovernmental Panel on Climate Change (IPCC) definition, resilience is the 'ability of a particular social or ecological system, of absorbing troubles while maintain the same structure and mode of operation, 
the ability of self-organization and the ability to adapt to stress and changes' (IPCC, 2007). Therefore, it is necessary to understand how an environment system organizes and transforms over time, being able to change and adapt without undermining its eco-social basis. Enhancement of the community resilience of an agricultural system means acting concretely in order to reduce its vulnerability while enhancing its adaptiveness in case of environmental degradation processes as well as its ability to face risks and instability.

The term 'sustainability' has been defined as the development which fulfills the requirements of present without compromising the capability of future generations to meet their own needs, as an accepted mutual goal in the UN Conference on Environment and Development (UNCED) in 1991. The 'Sustainable Land Use Management (SLM)' concerns on solutions that go far the technologic commendations by counting on the social participation and policy dialogue aspects in to consideration (Dumanski, 1994). The lately suggested "multi-level stakeholder approach to SLM" affords for encourage local level participation and also consents the presence of other stakeholders in the land use planning which is negotiated via common agreement (Hurni,1997).

Sea water intrusion has been identified as the main problem for declining of paddy cultivation in the coastal belt of wet and semi wet areas of Galle, Kalutara, Colombo and Gampaha Districts in Sri Lanka and a similar situation has also been reported in Jaffna, Manner, Puttalam and Trincomalee districts of coastal part of the Dry Zone of Sri Lanka (Sirisena, 2010). In this situation more than $50 \%$ of paddy lands in coastal river basins of Sri Lanka (around 0.115 million hectares) have been abandoned and converted into other unproductive enterprises (CCD, 2006).During dry season, salt water 
intrudes into lands up to $50 \mathrm{~cm}$ above mean sea level in the coastal belt of Sri Lanka and as a result of that rice growing soils in the coastal belt of Sri Lanka are salinized annually, making rice growing extremely difficult (Dimantha, 1977).

The Bentota area is predominantly an agricultural land and out of the 2524 hectares of paddy lands cultivated in year 1983, only 245 hectares of paddy lands have been cultivated during year 2013. Correspondingly, 637, 124 and 49 hectares of abandoned paddy lands have been converted to marshy lands, grasslands and scrubs during last three decades. It is depressed to identify 1385 hectares of abandoned paddy lands still remaining without utilizing for any purposes. Sirisena et al (2010) identified that except use of salt tolerance rice varieties, other management practices are difficult to adopt in coastal paddy lands. Silva (1977) showed that constructed salt water exclusion structures in the early 1970s were not a solution to control salt water intrusion. The saltwater intrusion in to major tributaries located in left bank of the river basin is higher during dry periods and threatened to the livelihood of that area (Piyadasa and Dineshika 2013, Piyadasa and Wijesundara 2014).

\section{Methodology}

Participatory approach was considered as the core of the entire study. With the participation of multiple strata community and government sector stakeholders, this study was conducted using the toolkit for the Indicators of Resilience in Socio-ecological Production Landscapes and Seascapes (UNUIAS, Biodiversity International, IGES and UNDP, 2014). The SEPALS toolkit claims having the prospective to be one of the most effective tools for "not only measuring, but also raising awareness of the concept of resilience in the field of sustainable development" (Yeboah,2014). The toolkit was 
translated in to local language where the necessary descriptions and analytical questions were changed in order to adapt the toolkit to the local setting. The findings are grounded on the community understandings followed with a comprehensive literature review, field visits and observations of the areas in interest. Following the toolkit of SEPALS methodology, the historical transformation, present context and the future trends associated with the development of the area followed in the resilient assessment community workshops was directed to capture the diverse details with reference to the 20 indicator under five major performance criteria (Table 1). Accordingly, several community resilient assessment workshops and focused group discussions were conducted covering Pahalagamhaya and Gonagalapura Agrarian Services areas in Bentota DSD. The analysis was carried out on identifying the possible challenges for the landscape combining the outcomes of all the conducted workshops. The results of the analysis were interpreted based on the dynamic environmental, socio economic and physical context of the Bentota area as a socio economic production landscape centered on the paddy cultivation of the area. The analysis was carried out as an integration of the cover-ups indicated in Table 2.

\section{Results and Discussion}

Contextual overlay of Bentota area in terms of its current land use pattern was analyzed using 'participatory mapping' tool, which is a very productive tool that can be applied to identify existing land use pattern of the area. Land use pattern and related spatial factors of the area was updated by consulting community members representing various strata of the society related to paddy cultivation at stakeholder meetings. The gathered information was digitized using Arc GIS software to create existing land use map of the area 
especially including the cultivating and abandoned paddy lands. Table 1 indicates the twenty indicators under five major performance criteria which the community members participated in scoring exercise following the discussion forum. The participants were requested to assign the level of resilience of their landscape in an order of 1 for lower level to 5 for higher level for each indicator, where the overall results have derived a spectrum of perceptions held by the community regarding the performance level of their own landscape. As illustrates in Table 3, the Bentota DSD expresses lower level near to moderate level in each indicator of the five major performance criteria in concern.

Under the performance criteria one, the Landscape/ Seascape diversity \& ecosystem protection, the uses of agricultural lands are changing time to time due to the change of economic value generated via market demand of the pertaining production and income generated from the cultivation trends in Bentota area. According to the community participants, the profitability of paddy cultivation is unpredictable and lesser than other Commercial crops. For example, the productive period of a paddy land ends in six months after harvesting one time. But the productive period of a proper Tea or Cinnamon cultivation extends up to more than fifteen years and if it is Rubber cultivation the productive period will be not less than twenty years. Agriculture in the area is severely facing the issues related to lack of labor forces. Especially the Paddy cultivation and Rubber cultivation are being rapidly collapsing at present due to lack of labor force and higher production input costs underlined. Hence mostly the local cultivators are profit oriented and selecting the most profitable crop at the given movement without considering the Land Suitability or any other environmental factors before converting their Agricultural Land use at the present time. Due to these reasons the participants have allocated the marks ranging from low to 
moderate where the future of paddy cultivation is at the most risk according to their perceptions. Under the indicator Ecosystem Protection, the participants indicate that the development activities along the Dedduwa lake side and along the coastal belt plus the less concern of the community have led to the degradation of the natural ecosystems of the region. Due to the lack of ecosystem protection, the Bentota River increasingly faces salt water intrusion and most of the paddy lands are abandoned as a counter result as well.

Under the performance criteria two, Biodiversity (Including Agricultural Biodiversity), the participants explained a very negative trend to the future of the area's paddy cultivation. In past decades the farmers got together and dredged the canals running via their paddy lands using manual labor and simple equipment in a way compatible to the environment while considering the proper proportionate depth and width of the canals during 1960's. But the Canal Dredging projects conducted by the Department of Irrigation nowadays are despondently questionable due to the incompatible technical mechanisms that are utilized in the process Eg:Polkadalagoda, Hipanwatta . Using machines usually tend to dredge the canal deeper than required therefore salt water is easily intruding in to the paddy lands. Due to this the productivity of the paddy lands has severely reduced and paddy lands are tending to neglecting in long term. Local Farmers indicate that it was possible to harvest more than $100 \mathrm{kgs}$ rice per cultivated paddy acre previously but this has been heavily reduced in half due to salt water intrusion. And also, the deeper and wider canals are attracting crocodiles which have become a massive threat for the community either sides of these canals. Siltation in paddy lands from the siltation of cannels is also another issue for abandoning the paddy lands in Kandemulla and Maha Induruwa area since year 1970 and still relevant institutions are failed to provide proper 
solution due to lack of cooperation among them. In manual dredging, the farmers repaired the either sides of the canal banks using the dredged soils as an access path along the canal for their paddy lands. Due to mechanical dredging these access ways are not facilitated and blocked where the farmers are unable even to take a Tractor to the paddy fields. And also, people illegally cultivate along the canal reservations and this also leads to block the access ways. All these activities have severely undermined the level of community resilience as well as the landscape resilience of the area especially in terms of paddy cultivation.

The third performance criterion knowledge and innovation indicates 2.85 of the mean rating value which also is lower that moderate level. The modern technological inputs and knowledge extended to all the cultivators equally by the Agrarian officers assigned for all the cultivations. Ex: Rubber, Tea, Coconut and paddy. Traditional Knowledge transfer to the future generations is rarely observable in Bentota area due to the lack of interest in Younger generation to engage in paddy cultivation. Ownership of the canals belongs to various institutions such as Irrigation Department, Minor irrigation Department and Divisional Secretariat. Some of the canals are neglected because nobody takes the responsibility and this leads to conflict of interest among the institutions and among the farmers as well. Though there are local paddy varieties used by local farmers at present the knowledge is rarely passed to the next generations. Especially the community stressed on the point that no one to preserve the local paddy seed varieties which are highly resilient to the local weather conditions and also even for the salinity levels as well. But the peers among the farmer communities still believe that the traditional ways of thinking, working and the lifestyle would be a proper solution for the frustrations faced by the younger generation in contemporary society. But the participants have assigned the highest performance value of 
3.09 mean rating to the fourth performance criteria Governance and equity indicating that Socio economic infrastructure, Human Health \& environmental condition, Income diversity, biodiversity based livelihoods and Socio- ecological mobility are moderately equal to everyone in the society. Under the fifth criteria Livelihood and Wellbeing, people describe that with the introduction of open economy in the country during year 1971, more job opportunities in various industries, garment, hotels etc were opened up. People tend to tap those opportunities and their interest to engage in paddy cultivation and related activities gradually decreased since new jobs are ensured steady income not like the paddy cultivation which always make instability in income. Paddy cultivation has faced declining while the following income generation activities are popularized in the region at present especially among the Young generation.

According to the discussion followed by the score card activity, the performance criteria 'Landscape diversity and ecosystem protection' of the Bentota DSD is facing multiple issues comparative to the other considered performance criteria. At the same time other than the Governance and equity none of the rest performance criteria exceed moderate level performance as denoted in Mean Rating of Figure 1. The results of the assessment thoroughly agree with the observations of the study area that the community of the area is in a considerable level of disappointment regarding addressing the Paddy cultivation related increasing issues of the area. Community efforts in this regard also do not have a significant impact in solving the rapidly complexing paddy fields abandoning problem.

The statements made by the community participants during the workshop were analyzed using the Nvivo 10 Word Cloud, Tree Map \& Cluster Analysis in order to identify the most stressed points discussed under the 
forum. Accordingly, the paddy cultivation was the foremost discussed topic while issues were conjoined with water, land and knowledge related matters as well. Salt water intrusion in to paddy fields, non-renovating of water canal network, huge spread of Wel Attha, Diyapara and Beru species and legal barrier for utilization abandoned paddy lands for other crop cultivation are observed as high priority issues. Lack of skilled laborers for farming, high initial cost and poor paddy harvest, availably of high water saturated paddy lands and poor maintenance of sluice gates and culverts are observed as moderate priority issues. Few farmers indicate the poor accessibility and no entrance for their paddy fields in order to take the vehicles in to paddy lands as a low priority issue.

The community participants expressed their opinion on future development trend of Bentota DSD (Figure 2) under each in 20 indicators by stating whether the future development would be downward trend or upward trend or no change in future. Community participants believe that there will not be upward development trend in all indicators excluding the indicator of Innovation in agriculture \& Conversation Practices. Communities believe that the new technological innovation in agriculture and conservation practices will be developed and helpful in future if they tend to cultivate abandoned paddy lands towards the enhancement of land productivity. Future development will focus to survive from the area itself in terms of agricultural production of paddy, coconut, local vegetable and fruits by introducing suitable strategies for optimizing the land productivity of abandoned paddy lands in future. Preservation the marshy and abandoned paddy lands in high and moderate flood affected areas is necessary to compromise its nature as flood buffers. 
Irrigation canal system in the area needs to renovate for supplying irrigation water for paddy cultivation by enhancing proper connectivity among separate small canals, lakes, river and proposed water retention ponds. A massive requirement exists for the renovation of Marine Dam (Karijja Wella). High water saturated and abandoned paddy lands (Hal Kumburu) in the area are feasibly suggested to convert as water retention ponds which enable to avoid flooding, water pollution, land degradation and to promote inland fishery and entertainment places for people to gather and enjoy. There available multiple opportunities to cultivate Kirala, Kekatiya, Pothuwila, Olu, Manel, Lotus as aquatic flora cultivations in the abandoned paddy lands and wasted marshes where Beru and Diyapara destroying the ecosystems. Floating farm tradition would be possible to introduce for additional crop cultivations in abandoned paddy lands without distressing its role on acting as flood buffer and there will not be any legal barrier for this type of crop conversion. Salt tolerance paddy varieties (Pokkali, at 354, Nona Bokra and at 401) would be encouraged to cultivate in saline water intrusion area by ensuring the expected harvest through an illustration of successful practical case.

Farmers who prefer to do traditional and organic farming should be encouraged by providing incentives and a proper market for their products. Practical knowledge related to traditional farming must be transferred to the younger generations by introducing a proper education mechanism related to productive agriculture. There should be a method to share the traditional knowledge among the farmers across the regions of the country as well. The reintroduction of rush and reed species to household paddy fields for processing into value-added handicraft products is essential for enhancing the local economy by utilizing abandoned paddy lands in the area. Bottle Caps used for Aurveda medicine were produced using species Kirala and 
Wel-aatha until year 2000 and currently these industries are fading away due to lesser demand. If this industry exists it will naturally control the spread of Wel-aatha trees which has become a severe threat for abandonment of paddy lands.

This study highly recommends that soil condition of several abandoned paddy lands is suitable for cinnamon cultivation where spreading 'Beru' trees. Deployment of coastal abandoned paddy lands for coconut cultivations is productive and toddy and coconut honey industry which was very rich and popular in the area during 1980's can be promoted again towards the higher local economy. There is a requirement to amend the paddy land policies to be directed towards the removal of the existing constraints on the conversion of abandoned paddy lands into other more profitable uses in areas where paddy cultivation has become increasingly unprofitable, dispelling the myth that paddy cultivation ensures food security at the level of the household for its entire labour force.

\section{Conclusion}

According to the overall assessment of landscape level community resilient capacity, the diversity and protection of the Bentota region is facing multiple issues comparative to the other considered measures. The community participants indicate below-moderate level resilience capacity for the paddy cultivation related landscape in Bentota and they are in a considerable level of disappointment regarding addressing the paddy cultivation related increasing issues of the area. Community efforts in this regard also do not have a significant impact in solving the rapidly growing paddy fields abandoning problem due to SWI. This study identified several issues in contradiction of the utilization of abandoned paddy lands in the area. Salt 
water intrusion in to paddy fields, non-renovating of water canal network, spread of Wel attha, Diyapara and Beru species and legal barrier for paddy lands conversion are observed as high priority issues. Lack of farming labourers, high initial cost and poor paddy harvest, high water saturated paddy lands and poor maintenance of sluice gates are observed as moderate priority issues. Comparative to the precedent studies and pre-workshop observations these results are highly compatible where the necessity of strategic intervention in sustainable land use management is highly in request for this area. Hence several land management strategies were identified to utilize abandoned paddy lands and to enhance community resilience in the area by overcoming those identified issues.

\section{References}

CCD (2006) Revised coastal zone management plan. Coast Conservation Department and the Ministry of Fisheries and Aquatic Resources. Available from: <http://www.coastal. gov.lk/downloads/pdf/CZMP\%20English.pdf>. [24 September 2016].

Dimantha, S. (1977) Soils of the low lying areas of West and South-West Sri Lanka, their properties and management. Tropical Agriculturist.cxxxiii:13-28.

Dumanski, J. (1994) Workshop Summary. Proceedings of the international workshop on sustainable land management for the 21st century (Vol 1). Agric Inst of Canada, Ottawa.

Hurni H. (1997) Concepts of sustainable land management; ITC Journal 1997-3/4

IPCC, 2007: Climate Change 2007: Impacts, Adaptation and Vulnerability. Contribution of Working Group II to the Fourth Assessment; Report of the Intergovernmental Panel on Climate Change, M.L. Parry, O.F. Canziani, J.P. Palutikof, P.J. van der Linden and C.E.Hanson, Eds., Cambridge University Press, Cambridge, UK, 976pp.

Piyadasa R.U.K. and Wijesundara. K. (2012) Saline Water Intrusion along the River Bentota and its Impact on Irrigation Water. Proceedings of International Forestry and Environment 
Symposium, Sri Lanka. Published by Department of Forestry and Environmental Science, University of Sri Jayewardenepura, vol 18, pg 68

Piyadasa, R.U.K and Dhineshika, K.D.C. (2013) Salinity intrusion and its impact on Groundwater quality - Case study in downstream of Bentota River Basin, Sri Lanka. Asia Water Week 2013, Retriveed from http://www.iwawaterwiki.org.

Silva, S.H.C.D. (1977) Engineering problems of flood control and drainage in the low lying lands of the wet zone in Sri Lanka.83,712.

Sirisena,D.N. (2010) Productivity improvement of saline paddy fields in Sri Lanka. A case study in Puttalam District. Rice Research and Development Institute, Batalagoda, Ibbagamuwa, Sri Lanka. AFACI Project Report.

UNU-IAS, Biodiversity International, IGES and UNDP (2014) Toolkit for the Indicators of Resilience in Socio-ecological Production Landscapes and Seascapes (SEPLS).

Yeboah, A.O. (2014) Ghana National Biodiversity Committee Toolkit for the Indicators of Resilience in Socio-ecological Production Landscapes and Seascapes (SEPLS). 
Table 1: The SEPLS 20 Indicators List

\begin{tabular}{|c|c|}
\hline Performance criteria & Indicators \\
\hline $\begin{array}{l}\text { 1. Landscape diversity \& } \\
\text { ecosystem Protection }\end{array}$ & $\begin{array}{l}\text { 1. Landscape/ Seascape diversity } \\
\text { 2. Ecosystem Protection } \\
\text { 3. Ecological Interactions between different components } \\
\text { of the Landscape/ seascape } \\
\text { 4. Recovery \& regeneration of the Landscape/ seascape }\end{array}$ \\
\hline $\begin{array}{l}\text { 2. Biodiversity (Including } \\
\text { Agricultural biodiversity) }\end{array}$ & $\begin{array}{l}\text { 5. Diversity of Local Food System } \\
\text { 6. Maintenance \& use of local crop varieties \& animal } \\
\text { breeds } \\
\text { 7. Sustainable Management of Common Resources }\end{array}$ \\
\hline 3. Knowledge \& Innovation & $\begin{array}{l}\text { 8. Innovation in agriculture \& Conversation Practices } \\
\text { 9. Traditional knowledge related to biodiversity } \\
\text { 10. Documentation of Biodiversity Associated Knowledge } \\
\text { 11. Women's knowledge }\end{array}$ \\
\hline $\begin{array}{l}\text { 4. Governance \& Social } \\
\text { Equity }\end{array}$ & $\begin{array}{l}\text { 12. Rights in relation to land /water \& other natural } \\
\text { resource Management } \\
\text { 13. Community based Landscape / Seascape Governance } \\
\text { 14. Social capital in the form of cooperation across the } \\
\text { Landscape } \\
\text { 15. Social Equity (including gender equity) }\end{array}$ \\
\hline 5. Livelihoods \& Wellbeing & $\begin{array}{l}\text { 16. Socio Economic Infrastructure } \\
\text { 17. Human Health \& Environmental Condition } \\
\text { 18. Income Diversity } \\
\text { 19. Biodiversity - Based Livelihoods } \\
\text { 20. Socio- Ecological Mobility }\end{array}$ \\
\hline
\end{tabular}

Source: Compiled by using UNU-IAS, Biodiversity International, IGES and UNDP; 2014 
Table 2: Analysis and Interpretation Methodology (Centered on Paddy Cultivation)

\begin{tabular}{|l|l|}
\hline \multicolumn{1}{|c|}{ Exercise } & \multicolumn{1}{c|}{ Analysis Method } \\
\hline 01. Community Mapping Exercise & $\begin{array}{l}\text { Contextual Overlay Analysis: Consider common } \\
\text { pattern using Arc GIS software by digitizing the } \\
\text { identified spatial factors }\end{array}$ \\
\hline 02. History Line Preparation & $\begin{array}{l}\text { Critical Life Event Pattern Analysis (CEP)- } \\
\text { comparison of the major life events and discuss } \\
\text { regarding the possible patterns in emergence of } \\
\text { contextual issues related to sustainable land use } \\
\text { management }\end{array}$ \\
\hline $\begin{array}{l}\text { 03. Socio-ecological Production } \\
\text { Landscapes and Seascapes } \\
\text { (SEPLS) 20 Indicators Forum }\end{array}$ & $\begin{array}{l}\text { Nvivo 10 - Word Cloud, Tree Map \& Cluster } \\
\text { Analysis - Identification of the most frequent } \\
\text { discussed issues and pertaining reasons }\end{array}$ \\
\hline $\begin{array}{l}\text { 04. Socio-ecological Production } \\
\text { (SEPLS) 20 Indicators Scoring } \\
\text { exercise }\end{array}$ & $\begin{array}{l}\text { Socio Economic Production Landscape Indicator } \\
\text { Data Capture Tool and Trend Analysis using Excel } \\
\text { and Statistical methods }\end{array}$ \\
\hline
\end{tabular}

Source: Compiled by Authors

Table 3: The SEPLS scoring results for Bentota area

\begin{tabular}{|l|l|l|l|l|}
\hline \multicolumn{1}{|c|}{ Performance Criteria } & $\begin{array}{c}\text { Lowest } \\
\text { third }\end{array}$ & $\begin{array}{c}\text { Mean } \\
\text { rating }\end{array}$ & $\begin{array}{c}\text { Highest } \\
\text { third }\end{array}$ & \multicolumn{1}{|c|}{$\begin{array}{c}\text { Standard } \\
\text { dev. }\end{array}$} \\
\hline $\begin{array}{l}\text { Landscape diversity and ecosystem } \\
\text { protection }\end{array}$ & 2.55 & 2.76 & 2.89 & 0.50 \\
\hline Biodiversity (including agriculture) & 2.44 & 2.98 & 3.68 & 0.77 \\
\hline Knowledge and innovation & 2.42 & 2.85 & 3.25 & 0.73 \\
\hline Governance and social Equity & 2.93 & 3.09 & 3.13 & 0.57 \\
\hline Livelihoods and well-being & 2.82 & 2.79 & 3.51 & 0.56 \\
\hline
\end{tabular}

Source: Compiled using the SEPLS scoring in Bentota area, 2017 


\section{Figure 1: SEPLS performance chart}

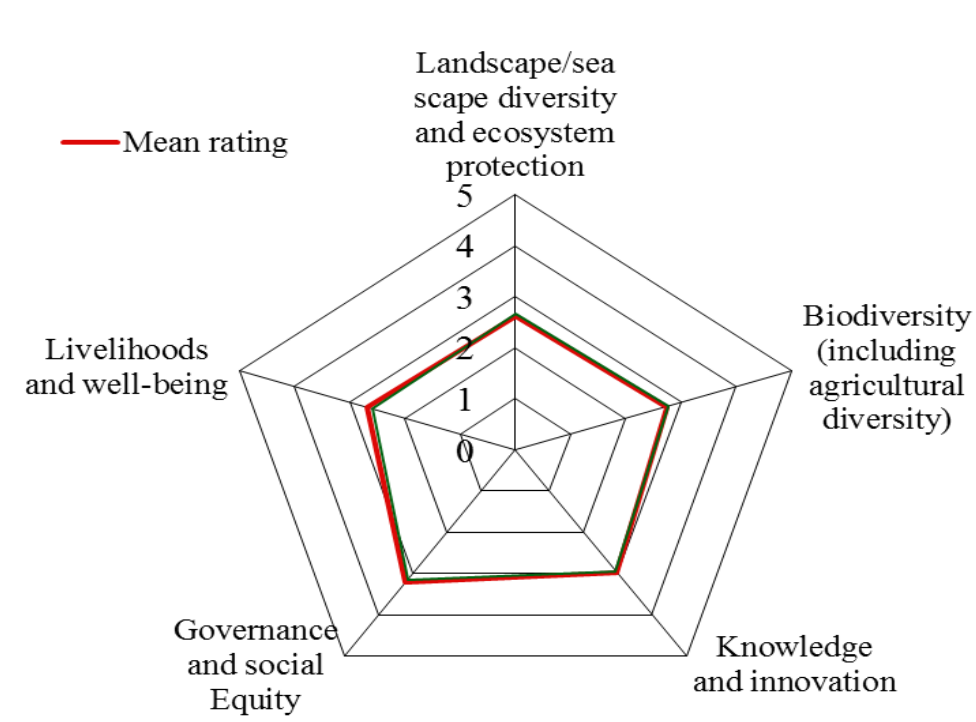

Source: Generated using Community Assessment results, 2017

Figure 2: The Future development trends of SEPLS performance

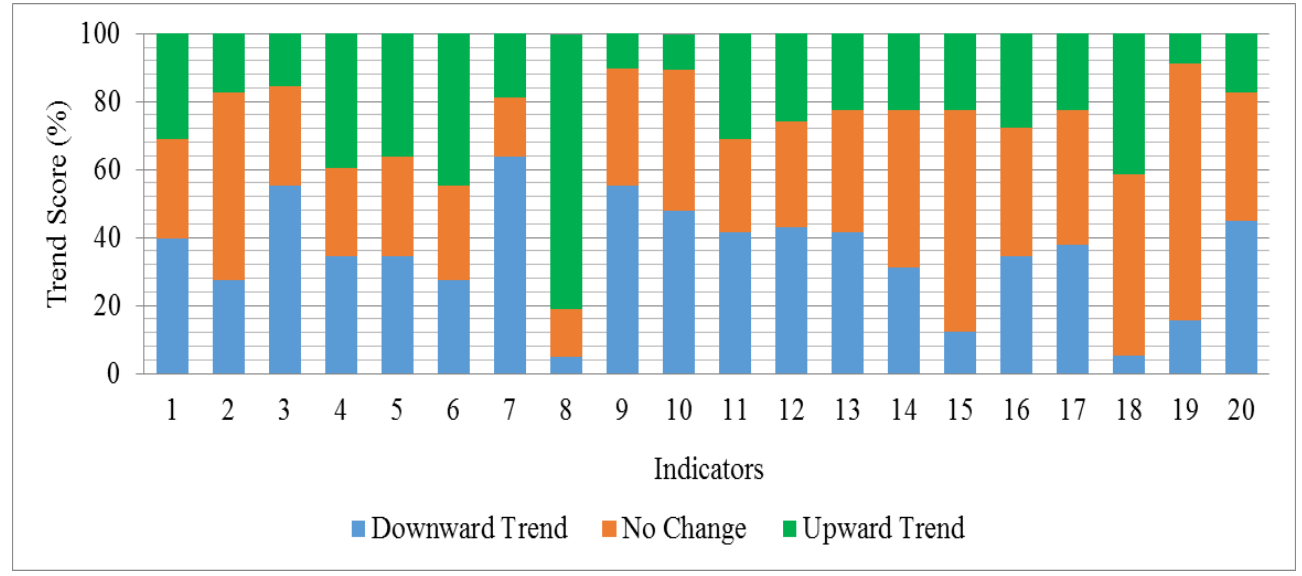

Source: Generated using Community Assessment results, 2017 